\title{
An Investigation of Pre-Service Science Teachers' Technological Pedagogical Content Knowledge
}

\author{
Bilge Can \\ Pamukkale University, Turkey
}

\author{
Secil Erokten \\ Pamukkale University, Turkey
}

\author{
Asiye Bahtiyar * \\ Pamukkale University, Turkey
}

\begin{abstract}
In order to reflect the integration of the teachers' content knowledge, pedagogical knowledge, and technology usage skills to the class context and to provide the expected outputs for the program's purposes, it is needed to be revealed the different dimensions of Technological Pedagogical Content Knowledge (TPACK). In this study, it was aimed to investigate the teacher training programmes related to pre-service science teachers' TPACK. This study was designed as a cross-sectional study. In the 2015-2016 academic year, a total of 269 pre-service teachers $(73$ of them from 1st grade, 73 of them from 2nd grade, 87 of them from 3rd and 36 of them from 4th grade students) attending Science Education Department participated in this study. As a data collection tool, 7 subscales of "Technological Pedagogical Content Knowledge Scale of Pre-Service Teachers"; namely, technology knowledge, pedagogical knowledge, content knowledge, technological pedagogical knowledge, technological content knowledge, pedagogical content knowledge, and technological pedagogical content knowledge were used. According to the results, as the class level of preservice teacher increases, their level of technological pedagogical content knowledge increases as well. Moreover, there is a significant difference on behalf of pre-service teachers at the 1 st grade in all dimensions of technological pedagogical content knowledge scale.
\end{abstract}

Keywords: TPACK, science curriculum, pre-service science teachers.

To cite this article: Can, B., Erokten, S., \& Bahtiyar, A. (2017). An investigation of pre-service science teachers' technological pedagogical content knowledge. European Journal of Educational Research, 6(1), 51-57. doi: 10.12973/eu-jer.6.1.51

\section{Introduction}

Today, societies to train individuals who can survive, decide alone and solve problems, they need to use and improve technology. Hence, the importance of training individuals who use technology is also increasing. One of the requirements of learners using and improving technology is the teachers who are using technology well and effectively and combining it with in class activities. Ministry of National Education (hereafter MONE) (2005), has also described competence of using technology effectively in courses as one of the teacher competencies. Not only in Turkey, but also all over the world, there are studies claiming that in order to teachers integrating technology with teaching effectively, creating opportunities and suggesting projects for them are also essential (Bhattacherjee \& Premkumar, 2004; Govender \& Govender, 2009). In recent years, these kinds of applications have become a study area of teacher trainers as an approach that defines teachers' effective technology integration knowledge. Technology integration is seen as an important component of effective teaching nowadays (Pierson, 1999).

In Turkey, as a result of research studies done in science education in 2004, the name of Science course was changed as 'Science and Technology'. Teaching methods, attainments, and class infrastructure were enriched with technology (MONE, 2005). That subsequently, Instructional Technologies and Material Design and Computer courses were added to science teacher training programmes in faculties of education by Higher Education Council (hereafter HEC). Material development courses aim to inform pre-service teachers about instructional technology, material design and instructional design (HEC, 2007). Thus, a theory has been used for teachers how to integrate technology and education. This theory is Technological Pedagogical Content Knowledge (TPACK), addition of technology knowledge to Pedagogical Content Knowledge (PCK) which was imparted to literature by Shulman (1986). TPACK has become a research focus of teacher trainers and researchers from many countries in recent years as an approach which defines teachers' effective technology integration knowledge (American Association of Colleges for Teacher Education [AACTE], 2008). Educators have started to develop TPACK concept by adding technological knowledge to pedagogical content knowledge (Mishra \& Koehler 2006; Angeli \& Valanides, 2009). TPACK theoretical framework is consisted of eight knowledge structures (Figure 1).

\footnotetext{
* Corresponding author:

Asiye Bahtiyar, Pamukkale University, Faculty of Education, Turkey

Email: asiye.bahtiyar@gmail.com
} 


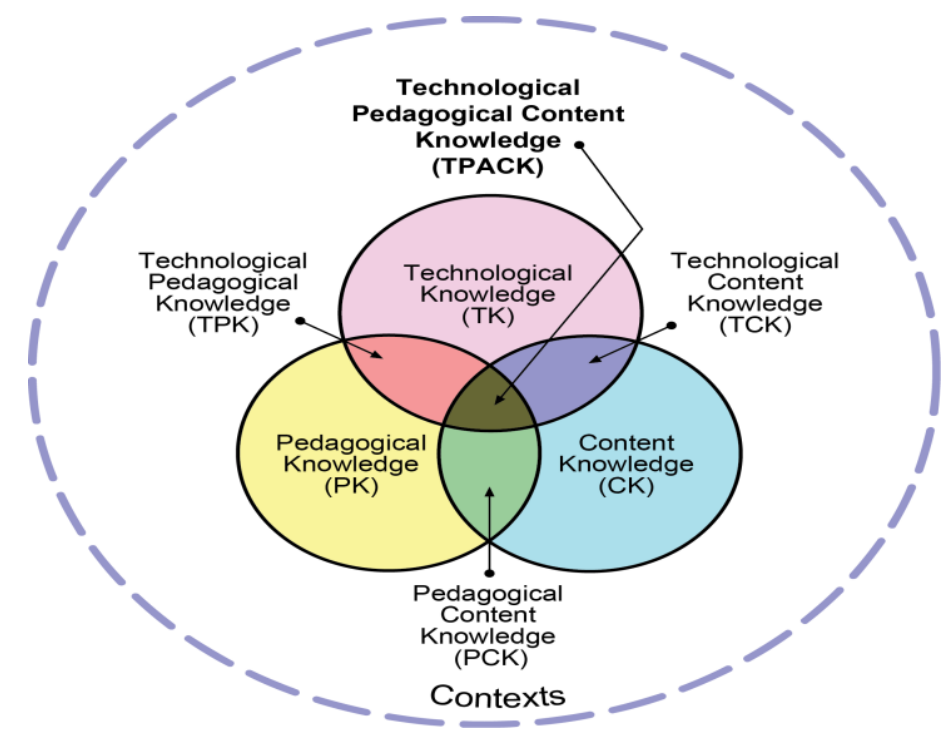

Figure 1. TPACK and Knowledge Types that TPACK Interact with (Koehler \& Mishra, 2009, p. 63).

- Pedagogical knowledge (PK), is the knowledge about teaching and learning process and its application such as students' learning process, classroom management, developing lesson plan, applying and evaluating.

- Technological knowledge (TK), is the knowledge of using information technology, hardware, software and tools.

- Pedagogical content knowledge (PCK), is the pedagogical knowledge applied to teach specific content as similar to Shulman's study.

- Technological pedagogical knowledge (TPK), is the knowledge of using pedagogical design and strategies appropriate to technological devices used in other words when a specific technology is used knowing of how teaching and learning will change.

- Technological content knowledge (TCK), is the knowledge of how technology is used in developing course content, visualising the content or conducting related studies and knowledge of what the specific technologies are related to the field (Koehler \& Mishra, 2008, p. 12).

Koehler \& Mishra (2005), are claiming that those models are moving towards from technology focused models to pedagogical focused models. While technology focused models are aiming to teachers acquire knowledge and skills of technology using; pedagogical focused models on the other hand aim to teachers integrate technology use with pedagogical knowledge in teaching process. One of the prominent models of pedagogical focused models in technology integration into education is Technological Pedagogical Content Knowledge model (Koehler \& Mishra, 2005). TPACK model should be demonstrated with various dimensions in order to combine and apply teachers' content knowledge, pedagogical knowledge and technological knowledge effectively and reflect it on classroom effectively and in order to get expected outcomes consistent to the programme's aims. Detail analysis of application of this model which was shaped as a theory should be conducted. Technology integration of teachers should be carried with various dimensions by determining teachers' TPACK skills with appropriate models and developed measurement tools.

Teacher training institutions should also make the necessary efforts to train teachers suited to requirements of this age. Teachers should have the ability to use technology in order to develop materials besides in the course planning and preparing for the course. Therefore, they should be able to integrate technology knowledge into teaching processes. So, the teacher training institutions should have a great role (Ay, 2015).

Many research studies which examine teacher or pre-service teachers' TPACK have been found (Harris \& Hofer, 2011; Jaipal \& Figg, 2010; Jang \& Chen, 2010; Niess, 2005; Terpstra, 2009; Wilson \& Wright, 2010; Timur ve Tasar, 2011; Kaleli Yilmaz, 2015). However, the effect of teacher training programmes on pre-service science teachers' TPACK has not been examined. In this study, teacher training programmes on pre-service science teachers' TPACK were examined.

\section{Methodology}

\section{Research Design}

This study has descriptive survey approach. The simple descriptive survey approach is one-shot survey for the purpose of describing the characteristics of a sample at one point in time apart from the other approaches of survey research namely cross-sectional and longitudinal (Mertens, 1998, p.108). This research is a cross-sectional study conducted for the purpose of describing how a four semester sequence teacher education program helps change pre-service teachers' TPACK. For this purpose, the data was collected from each class level separately at the same period. 


\section{Sample}

This study was conducted in 2015-2016 academic year fall semester. 1st, 2nd, 3rd, and 4th year students who are studying in Science Education Department of a Faculty of Education in Aegean region participated in the study. The study was conducted with 269 students, 73 of them from 1st grade, 73 of them from 2nd grade, 87 of them from 3rd and 36 of them from 4th grade students. First grade students are taking General Physics I-II, General Physics Laboratory I-II, General Chemistry I-II, General Chemistry Laboratory I-II, General Mathematics I-II, Introduction to Education Sciences, Psychology of Education courses; 2nd grade students are taking General Biology I-II, General Biology Laboratory I-II, General Physics III, Introduction to Modern Physics, Analytical Chemistry, Organic Chemistry, Computer I-II, Teaching Principles and Methods, Science and Technology Program and Planning courses; 3rd grade students are taking Human Anatomy and Physiology, Special Topics in Physics, Special Topics in Chemistry, Statistics, Laboratory Applications in Science Education I-II, Instructional Technologies and Material Design, Genetics and Biotechnology, Nature of Science and History of Science, Environmental Science, Earth Science, Special teaching Methods I, Measurement and Evaluation courses; 4th grade students are taking Philosophy of Education, Special Topics in Biology, Evolution, Special Teaching Methods II, School Experience, Guidance, Classroom Management, Astronomy, Teaching Practice, Turkish Education System and School Administration courses.

\section{Data Collection Tools}

As a data collection tool, "Technological Pedagogical Content Knowledge Scale of Pre-Service Teachers" was used (Sahin, 2011). The scale was consisted of 7 subscales. Those are, respectively, 15 items for technology knowledge (TK), 6 items for pedagogical knowledge (PK), 6 items for content knowledge (CK), 4 items for technological pedagogical knowledge (TPK), 4 items for technological content knowledge (TCK), 7 items for pedagogical content knowledge (PCK), 5 items for technological pedagogical content knowledge (TPACK). The scale rating was in the 5 points Likert as "Not At All Know", "Slightly Know", "Somewhat Know", "Moderately Know", and "Extremely Know".

\section{Analyzing of Data}

The responses given by the students were categorized as 1, 2, 3, 4, 5 and total scores were calculated. By calculating arithmetic mean for each item in the scale, arithmetic means were determined as degree of participation. Based on the assumption of that ranges are equal, arithmetic mean score range coefficient was found as 0.80 . The evaluation range of the arithmetic mean are as follows: (1) 1.00-1.80 "Not At All Know", (2) 1.81-2.60 "Slightly Know", (3) 2.61-3.40 "Somewhat Know", (4) 3.41-4.20 "Moderately Know", (5) 4.21-5.00 "Extremely Know". The lowest score to get from the applied scale is 46, and the highest is 230 . In order to determine whether data are in normal distribution, Kolmogorov Smirnov analysis $(Z=0.809 ; \mathrm{p}>0.05)$ was applied. According to Kolmogorov Smirnov analysis, the scores got from the scale by 1 st grade students $(Z=0.595, p>0.05)$, 2 nd grade students $(Z=0.726, p>0.05), 3$ rd grade students $(Z=0.564$, $\mathrm{p}>0.05)$, and 4 th grade students $(Z=0.554, \mathrm{p}>0.05)$ are in normal distribution. Cronbach's Alpha value was found as 0.962 for the scale. For the 1 st grade students $\alpha=0.951$, for the 2 nd grade students $\alpha=0.953$, for the 3 rd grade students $\alpha=0.943$ and for the 4 th grade students $\alpha=0.968$ were found. Descriptive statistics analysis of the scale used and oneway analysis of variance (ANOVA) were applied.

\section{Findings}

Findings related to whether pre-service science teachers' technological pedagogical content knowledge has shown a significant difference according to their grades are shown in Table 1.

Table 1. One-way ANOVA Result of Variation of Technological Pedagogical Content Knowledge According to Grades

\begin{tabular}{ccccccc}
\hline & $\begin{array}{c}\text { Source of } \\
\text { Variance }\end{array}$ & $\begin{array}{c}\text { Sum of } \\
\text { Squares }\end{array}$ & df & Mean Square & F & Sig. \\
\hline \multirow{2}{*}{ Grades } & Between Groups & 24,088 & 3 & 8,029 & 28,378 &, $000^{*}$ \\
& Within Groups & 74,980 & 265 &, 283 & & \\
\hline$* p<0.05$ & Total & 99,068 & 268 & & & \\
\hline
\end{tabular}

As seen in Table 1, as a result of one way ANOVA which was applied in order to determine whether there is a significant difference between pre-service science teachers' technological pedagogical content knowledge according to their grades, it has been determined that technological pedagogical content knowledge has shown a difference at 0.05 significance level according to grades ( $\mathrm{F}=28.378 ; \mathrm{p}<0.05)$.

Results of multiple comparison analysis (Tukey) applied in order to determine the direction of this difference to which grade or grades are shown in Table 2. 
Table 2. Multiple Comparison Analysis (Tukey) Values of Grades

\begin{tabular}{|c|c|c|c|c|}
\hline Grades & $1^{\text {st }}$ grade & $2^{\text {nd }}$ grade & $3^{\text {rd }}$ grade & $4^{\text {th }}$ grade \\
\hline $1^{\text {st }}$ grade & --- & $.000^{*}$ & $.000^{*}$ & $.000^{*}$ \\
\hline $2^{\text {nd }}$ grade & $.000^{*}$ & ---- & --- & $.002^{*}$ \\
\hline $3^{\text {rd }}$ grade & $.000^{*}$ & ---- & ---- & ---- \\
\hline $4^{\text {th }}$ grade & $.000^{*}$ & $.002^{*}$ & ---- & --- \\
\hline
\end{tabular}

As seen in Table 2, there is a significant difference in favour of $1^{\text {st }}$ grade pre-service teachers' technological pedagogical content knowledge when compared with other grades $(p<0.05)$. In addition, it is determined that there is a significant difference between $2^{\text {nd }}$ and $4^{\text {th }}$ grade pre-service science teachers' technological pedagogical content knowledge $(\mathrm{p}<$ 0.05). In order to determine to those differences are in favour of these which grades, total mean scores taken from technological pedagogical content knowledge scale were examined according to grades and related descriptive statistics were shown in Table 3.

Table 3. Descriptive Statistics Related to Mean Scores of Grades

\begin{tabular}{cccccc}
\hline Grade & N & Min. & Max. & $\bar{X}$ & Responses \\
\hline 1st $^{\text {srade }}$ & 73 & 1,74 & 4,19 & 2,7718 & Somewhat \\
$2^{\text {nd }}$ grade & 73 & 1,87 & 4,21 & 3,2690 & Somewhat \\
$3^{\text {rd }}$ grade & 87 & 1,72 & 4,51 & 3,3876 & Somewhat \\
$4^{\text {th }}$ grade & 36 & 2,51 & 4,74 & 3,6548 & Moderately \\
\hline TOTAL & 269 & 1,72 & 4,74 & 3,2241 & Somewhat \\
\hline
\end{tabular}

As seen in Table 3, it was determined that while $1^{\text {st }}$ grade pre-service science teachers have the lowest technological pedagogical content knowledge with the mean score of $2.7718,4$ th grade pre-service science teachers have the highest technological pedagogical content knowledge with the mean score of 3.6548. Besides, except 1st grade students, other three grades students' mean are higher than the mean score (3.2241) of all participating pre-service science teachers to the study.

Findings related to whether the scores taken by pre-service science teachers from subscales of technological pedagogical content knowledge scale have shown a significant difference according to their grades are shown in Table 4.

Table 4. One-way ANOVA Results of Variation of Subscales of Technological Pedagogical Content Knowledge Scale According to Grades

\begin{tabular}{|c|c|c|c|c|c|c|c|c|}
\hline Dimensions & & $\begin{array}{l}\text { Source of } \\
\text { Variance }\end{array}$ & $\begin{array}{c}\text { Sum of } \\
\text { Squares }\end{array}$ & df & $\begin{array}{c}\text { Mean } \\
\text { Square }\end{array}$ & $\mathbf{F}$ & Sig. & Source \\
\hline TK & Grades & $\begin{array}{c}\text { Between Groups } \\
\text { Within Groups } \\
\text { Total }\end{array}$ & $\begin{array}{c}18,690 \\
123,048 \\
141,738\end{array}$ & $\begin{array}{c}3 \\
265 \\
268\end{array}$ & $\begin{array}{c}6,230 \\
, 464\end{array}$ & 13,417 &, $00^{*}$ & $\begin{array}{c}1-2,1-3 \\
1-4\end{array}$ \\
\hline PK & Grades & $\begin{array}{c}\text { Between Groups } \\
\text { Within Groups } \\
\text { Total }\end{array}$ & $\begin{array}{c}34,217 \\
139,259 \\
173,476\end{array}$ & $\begin{array}{c}3 \\
265 \\
268\end{array}$ & $\begin{array}{c}11,406 \\
, 526\end{array}$ & 21,704 &, $00^{*}$ & $\begin{array}{l}1-2,1-3 \\
1-4,2-4\end{array}$ \\
\hline CK & Grades & $\begin{array}{c}\text { Between Groups } \\
\text { Within Groups } \\
\text { Total }\end{array}$ & $\begin{array}{l}16,315 \\
83,250 \\
99,565\end{array}$ & $\begin{array}{c}3 \\
265 \\
268\end{array}$ & $\begin{array}{c}5,438 \\
, 314\end{array}$ & 17,312 &, $00^{*}$ & $\begin{array}{c}1-2,1-3 \\
1-4\end{array}$ \\
\hline TPK & Grades & $\begin{array}{c}\text { Between Groups } \\
\text { Within Groups } \\
\text { Total }\end{array}$ & $\begin{array}{c}21,282 \\
132,482 \\
153,764\end{array}$ & $\begin{array}{c}3 \\
265 \\
268\end{array}$ & $\begin{array}{c}7,094 \\
, 500\end{array}$ & 14,190 &, $00 *$ & $\begin{array}{c}1-2,1-3 \\
1-4\end{array}$ \\
\hline TCK & Grades & $\begin{array}{c}\text { Between Groups } \\
\text { Within Groups } \\
\text { Total }\end{array}$ & $\begin{array}{c}38,985 \\
155,050 \\
194,034\end{array}$ & $\begin{array}{c}3 \\
265 \\
268\end{array}$ & $\begin{array}{c}12,995 \\
, 585\end{array}$ & 22,210 &, $00^{*}$ & $\begin{array}{l}1-2,1-3 \\
1-4,2-4\end{array}$ \\
\hline PCK & $\begin{array}{l}\text { Grades } \\
\text { Grades }\end{array}$ & $\begin{array}{c}\text { Between Groups } \\
\text { Within Groups } \\
\text { Total }\end{array}$ & $\begin{array}{c}38,985 \\
155,050 \\
194,034\end{array}$ & $\begin{array}{c}3 \\
265 \\
268\end{array}$ & $\begin{array}{c}12,995 \\
, 585\end{array}$ & 22,210 &, $00^{*}$ & $\begin{array}{l}1-2,1-3 \\
1-4,2-4\end{array}$ \\
\hline TPACK & Grades & $\begin{array}{c}\text { Between Groups } \\
\text { Within Groups } \\
\text { Total }\end{array}$ & $\begin{array}{c}37,295 \\
150,224 \\
187,519\end{array}$ & $\begin{array}{c}3 \\
265 \\
268\end{array}$ & $\begin{array}{c}12,432 \\
, 567\end{array}$ & 21,930 &, $00^{*}$ & $\begin{array}{l}1-2,1-3 \\
1-4,2-4\end{array}$ \\
\hline
\end{tabular}

When Table 4 is examined, there is a significant difference between $1^{\text {st }}$ grade students and $2^{\text {nd }}, 3^{\text {rd }}$, and $4^{\text {th }}$ grades students in all subscales of technological pedagogical content knowledge scale $(p<0.05)$. Moreover, there are significant differences in pedagogical knowledge (PK), technological content knowledge (TCK), pedagogical content knowledge (PCK) and technological pedagogical content knowledge (TPACK) subscales between $2^{\text {nd }}$ grade and $4^{\text {th }}$ grade 
pre-service science teachers $(\mathrm{p}<0.05)$. In order to determine to those differences are in favour of these which grades, descriptive statistics related to mean scores of subscales according to grades are shown in Table 5.

Table 5. Descriptive Statistics Related to Mean Scores of Subscales of Technological Pedagogical Content Knowledge Scale

\begin{tabular}{|c|c|c|c|c|c|c|c|}
\hline Grade & $\mathbf{N}$ & Dimensions & Min. & Max. & $\bar{X}$ & Sd & Response \\
\hline \multirow{7}{*}{$1^{\text {st }}$ grade } & \multirow{7}{*}{73} & TK & 1,00 & 5,00 & 2,8511 & ,76162 & Somewhat \\
\hline & & PK & 1,00 & 4,67 & 2,5434 & 89582 & Slightly \\
\hline & & $\mathrm{CK}$ & 1,33 & 4,67 & 2,7557 & 64793 & Somewhat \\
\hline & & TPK & 1,50 & 4,75 & 2,9110 & ,75504 & Somewhat \\
\hline & & TCK & 1,00 & 5,00 & 2,6678 & ,94102 & Somewhat \\
\hline & & PCK & 1,00 & 5,00 & 2,6678 & ,94102 & Somewhat \\
\hline & & TPACK & 1,00 & 4,60 & 2,6767 & ,90531 & Somewhat \\
\hline \multirow{7}{*}{$2^{\text {nd }}$ grade } & \multirow{7}{*}{73} & TK & 1,60 & 4,67 & 3,3489 & ,62416 & Somewhat \\
\hline & & $\mathrm{PK}$ & 1,83 & 4,50 & 3,1301 & 61000 & Somewhat \\
\hline & & $\mathrm{CK}$ & 1,50 & 4,33 & 3,1575 & ,48820 & Somewhat \\
\hline & & TPK & 1,50 & 5,00 & 3,4315 & 68625 & Moderately \\
\hline & & TCK & 1,50 & 4,75 & 3,2842 & 69387 & Somewhat \\
\hline & & PCK & 1,50 & 4,75 & 3,2842 & 69387 & Somewhat \\
\hline & & TPACK & 1,40 & 4,80 & 3,1452 & 69543 & Somewhat \\
\hline \multirow{7}{*}{$3^{\text {rd }}$ grade } & \multirow{7}{*}{87} & TK & 1,67 & 4,80 & 3,4176 & 64935 & Moderately \\
\hline & & PK & 1,50 & 5,00 & 3,2720 & 68300 & Somewhat \\
\hline & & $\mathrm{CK}$ & 1,67 & 4,67 & 3,2950 & ,53718 & Somewhat \\
\hline & & TPK & 2,00 & 5,00 & 3,4914 & 67605 & Moderately \\
\hline & & TCK & 1,75 & 5,00 & 3,4540 & 65429 & Moderately \\
\hline & & PCK & 1,75 & 5,00 & 3,4540 & 65429 & Moderately \\
\hline & & TPACK & 1,60 & 5,00 & 3,4414 & ,68345 & Moderately \\
\hline \multirow{7}{*}{$4^{\text {th }}$ grade } & \multirow{7}{*}{36} & TK & 2,20 & 5,00 & 3,5833 & ,69636 & Moderately \\
\hline & & $\mathrm{PK}$ & 2,00 & 5,00 & 3,6019 & 64522 & Moderately \\
\hline & & $\mathrm{CK}$ & 2,17 & 4,50 & 3,4491 & ,56177 & Moderately \\
\hline & & TPK & 2,00 & 5,00 & 3,7222 & ,72155 & Moderately \\
\hline & & TCK & 2,00 & 5,00 & 3,7917 & ,75238 & Moderately \\
\hline & & PCK & 2,00 & 5,00 & 3,7917 & ,75238 & Moderately \\
\hline & & TPACK & 2,60 & 5,00 & 3,7778 & 68080 & Moderately \\
\hline
\end{tabular}

According to Table 5, it is determined that when students get higher grade levels, the mean scores taken from subscales of technological pedagogical content knowledge scale also increase. It is also seen that especially pedagogical knowledge which is at "Not At All Know" level in the first grade , in $2^{\text {nd }}$ and $3^{\text {rd }}$ grade at "Somewhat Know" level, and in $4^{\text {th }}$ grade it increases to "Moderately Know" level and technological knowledge as at "Somewhat Know" level increases to "Moderately Know" level. It is also noteworthy that $4^{\text {th }}$ grade pre-service science teachers' technological pedagogical content knowledge with its all subscales reaches to "Moderately Know" level.

\section{Discussion and Conclusion}

As a result of the findings, when analysed according to grades, technological pedagogical content knowledge of preservice science teachers increases from 1 st grade to 4 th grade. When related literature are reviewed, Terpstra (2009) acknowledges about technology integration process that firstly technological knowledge of teachers improves, they start to improve ways of using technology in line with programmes, in other words, the emergence of technological pedagogical knowledge has seen. Savas, OztUrk and TUzUn (2010) stress that in order to pre-service teachers achieve technology integration effectively, primarily technological knowledge needs to be increased and then content knowledge and pedagogical knowledge competencies should be ensured.

Having mean score in favour of 4th grade students shows us that pre-service teachers who are taking Instructional Technologies and Material Design course in 3rd grade have an active role in developing software to use in field education, by means of various technologies creating 2D or 3D materials, developing teaching tools, and examining of educational software. In addition, the first course that they come across with science education and teaching, computer supported laboratory studies which is one of the aims of Laboratory Applications in Science Education II course, the topics such as the place and how to use of computers in laboratory are thought to be effective. In Special Teaching Methods II course, pre-service teachers have opportunities of practice via micro teaching by choosing topics from 5th and 8th grades secondary school Science Education Programme and preparing lesson plans and organising with suitable tools and materials. 
Also, having completed School Experience course may also increase their TPACK skills. Because, having done product or document analysis by determining evaluation criteria in their training schools' classrooms might be effective. At the same time, having done classroom management, data collection, data presentation and data sharing with specialist teachers in this course might be effective, too.

When TPACK sub scales that pre-service teachers have are examined according to their grades, there is a difference between 1st graders and other graders in all subscales; in addition, there are differences between 2nd graders and 4th graders in PK, TCK, PCK and TPACK subscales. Also, pre-service teachers who are studying in 2nd grade completed courses offered only in 1st grade, when they are studying in 4th grade they have already completed courses related to PK, TCK, PCK, TPACK placed in the programme and so it can be said that they can integrate technology into courses.

When findings of this study are examined, it can be said that the obtained results may based on 3 main reasons. One of them is TPACK topic is a brand new for pre-service teachers, and renewing science teacher training programme in 2006 and implementation of it by faculties of education after that.

Secondly, while pre-service science teachers haven't any real environments that they can apply what they have learned until 4th grade, in the last grade they have completed courses such as Special Teaching Methods I-II, School Experience, Instructional Technologies and Material Design, Laboratory Applications in Science Education I-II and they can create learning environments that they can reflect what they have learned. Despite having limited course hours of practical lessons in Science Teacher Training programme, it is seen that pre-service teachers have shown an improvement in using TPACK skills.

Lastly, in line with the results, we can conclude that academics who give teacher training are able to reflect TPACK into their in class applications.

\section{Suggestions}

- In line with those results, studies focusing on TPACK of academics in faculties of education may be carried.

- Also, the views of pre-service science teachers on TPACK may be examined with qualitative research studies in detail.

- When it is considered that TPACK is not important only for pre-service science teachers but also for pre-service teachers in other areas, it might be useful to carry this study with other pre-service teachers.

- There is an increase in TPACK studies in teacher training research and applications in Turkey. By making use of the results of this research, teacher trainers and researchers in education field may develop programmes for teachers to improve their technology integration knowledge or they can enhance current programmes.

- In line with the results of this study, it is suggested to use of micro teaching technique in Special Teaching Methods II course, one of the content courses, as foreseen by HEC in order to train and graduate pre-service teachers with professional competencies who take content and teaching profession courses until the last grade of their undergraduate studies.

\section{References}

American Association of Colleges for Teacher Education [AACTE]. (2008). Handbook of Technological Pedgagocial Content Knowledge for Educators (TPCK). New York: Routledge./Taylor \& Francis Group.

Angeli, C. \& Valanides, N. (2009). Epistemological and methodological issues for the conceptualization, development, and assessment of ICT-TPCK: Advances in technological pedagogical content knowledge (TPCK). Computers \& Education, 52(1), 154-168.

Ay, Y. (2015). Ogretmenlerin teknolojik pedagojik alan bilgisi (TBAP) becerilerinin uygulama modeli baglaminda degerlendirilmesi [Evaluation of teachers' technological pedagogical content knowledge (TPACK) within the framework of practical model]. Unpublished doctoral dissertation, Eskisehir Osmangazi Universitesi, Eskisehir.

Bhattacherjee, A. \& Premkumar, G. (2004). Understanding changes in belief and attitude toward information technology usage: A theoretical model and longitudinal test. MIS Quarterly. 28(2) 351-370.

Govender, D. \& Govender, I. (2009). The relationship between information and communications technology (ICT) integration and teachers' self-efficacy beliefs about ICT. Education As Change, 13(1), 153-165

Harris, J.B. \& Hofer, M.J. (2011). Technological pedagogical content knowledge (TPACK) in action: A descriptive study of secondary teachers' curriculum-based, technology-related instructional planning. Journal of Research on Technology in Education, 43 (3), 211-229. 
Jaipal, K., \& Figg, C. (2010). Unpacking the "Total PACKage": Emergent TPACK chracteristics from a study of preservice teachers teaching with technology. Journal of Technology and Teacher Education, 18 (3), 415-441.

Jang, S.J. \& Chen, K.C. (2010). From PCK to TPCK: Developing a transformative model of pre-service science teachers. Journal of Science Education and Technology, 19(6), 553-564.

Kaleli Yilmaz, G. (2015). TUrkiye'deki teknolojik pedagojik alan bilgisi calismalarinin analizi: bir meta-sentez calismasi. Egitim ve Bilim, 40 (178), 103-122. DOI: 10.15390/EB.2015.4087.

Koehler, M. J. \& Mishra, P. (2005). What happens when teachers design educational technology? The development of technological pedagogical content knowledge. Journal of Educational Computing Research, 32(2), 131-152.

Koehler, M. J. \& Mishra, P. (2008). Introducing TPCK. AACTE Committee on Innovation and Technology (Ed.), The handbook of technological pedagogical content knowledge (TPCK) for educators (pp. 3-29). Mahwah, NJ: Lawrence Erlbaum Associates.

Koehler, M. \& Mishra, P. (2009). What is technological pedagogical content knowledge? Contemporary Issues in Technology and Teacher Education, 9 (1), 60-70.

MEB, (2005). 6, 7, ve 8. siniflar Fen ve Teknoloji Ogretim Programi, Ankara.

Mertens, D.M. (1998). Research Methods in Education and Psychology: Integrating diversity with qualitative \& quantitative approaches. Sage Publications.

Mishra, P. \& Koehler, M. J. (2006). Technological pedagogical content knowledge: A framework for integrating technology in teachers' knowledge. Teachers College Record, 108(6), 1017-1054.

Niess, M. L. (2005). Preparing teachers to teach science and mathematics with technology: Developing a technology pedagogical content knowledge. Teaching and Teacher Education, 21(5), 509-523.

Pierson, M. E. (1999). Technology integration practice as a function of pedagogical expertise (Doctoral dissertation, Arizona State University). Dissertation Abstracts International, 60(03), 711. (AAT 9924200).

Savas, M., OztUrk, N. \& Tuzun, Y. O. (2010). Fen bilgisi ogretmen adaylarinin teknolojik pedagojik alan bilgilerinin incelenmesi, IX Ulusal Fen Bilimleri ve Matematik egitimi Kongresi Ozet Kitapcigi, Izmir: Guler Matbaacilik.

Shulman, L. S. (1986). Those who understand: knowledge growth in teaching, $\quad$ Educational Researcher, 4-14.

Sahin, I. (2011). Development of survey of technological pedagogical and content knowledge (TPACK), TOJET, volume 10 , issue $1,97-105$.

Terpstra, M. J. (2009). Developing technological pedagogical content knowledge: preservice teachers' perceptions of how they learn to use educational technology in their teaching. (Unpublished doctoral dissertation), Michigan State University. Michigan.

Timur, B. \& Tasar, M.F. (2011). Teknolojik pedagojik alan bilgisi oz guven olceginin (TPABOGO) Turkce'ye uyarlanmasi. Gaziantep Universitesi Sosyal Bilimler Dergisi, 10 (2), 839-856.

Wilson, E. \& Wright, V. (2010). Images over time: The intersection of social studies through technology, content, and pedagogy. Contemporary Issues in Technology and Teacher Education, 10 (2), 220-233.

Yuksekogretim Kurulu (YOK). (2007). Egitim Fakultesi Ogretmen Yetistirme Lisans Programlari. Ankara. 